\title{
Effects of HACCP system implementation on reproduction, milk quality, and milk sanitation on dairy farms in korea
}

\author{
Insik Nam* \\ Research center for environment friendly and quality livestock production technology, Hankyoung National University, Ansoung, Korea
}

\section{A B S T R A C T}

\begin{abstract}
The objective of this study was to investigate the influence of hazard analysis critical control point (HACCP) system implementation on the reproductive efficiency of dairy cattle, milk quality, and veterinary medicine use in dairy farms across Korea. Data were collected from 50 dairy farms before and after the implementation of the HACCP system. Importantly, somatic cell number and bacterial count in raw milk, and monthly expenses for medicine were lower after HACCP system implementation $(p<0.05)$. However, the breeding interval, use of different classes of antibiotics, milk protein, and milk fat content were not changed by implementing the HACCP system. These results indicated that implementation of the HACCP system on dairy farms may reduce the use of veterinary medicine and improve milk sanitation levels.
\end{abstract}

Keywords: HACCP; Implementation; Dairy cow; Milk; Quality; Sanitation

\section{INTRODUCTION}

The Korean livestock industry has been using the intensive livestock operation farming system to improve their maximum productivity within a limited area of land (Khan, 2006). However, the intensive livestock operation farming system has created many serious problems, such as reduced immune function and poor control of infectious diseases among animals (Hays, 1991; Chinabut and Puttinaowarat, 2005). To maintain higher productivity with better infectious disease control, animal producers began to use large quantities of antibiotics to prevent disease, as well as growth promoters in their animals. However, in recent years, antibiotic supplementation in animal diets has resulted in the development of microbial resistance to antibiotics. Furthermore, antibiotic residues in milk are hazardous to human health because of possible development of antibiotic resistance. Alarmingly, this scenario has been detected because of animal products (Rhodes et al., 2000; Suh and Song, 2006).

Recently, antibiotic overuse in the livestock industry has become a major issue of concern (Kim et al., 2005). The hazard analysis and critical control point (HACCP) system was originally developed in the 1960s to ensure safe food for astronauts and provide a specific and systematic approach to food quality control by allowing identification of hazards and the points at which they can be controlled (Dowson et al., 1994). In other countries, HACCP principles have been adapted for use at the farm level (Cullor 1995; Lean, 2000). In the case of dairy farms, Noordhuizen et al. (2008) developed a HACCP based program for use in quality risk management. The HACCP system was introduced by the Codex Alimentarius Commission (Codex Alimentarius Commission, 2007). Concerning product hygiene and safety in 1993, the Ministry of Agriculture, Food and Rural Affairs (MAFRA) in Korea began implementing the HACCP system in all livestock industries including animal farms, slaughterhouses, meat packing centers, livestock product processing centers, and meat markets. The implementation of the HACCP system in the swine, cattle, and poultry industry started in 2006, 2007, and 2008 , respectively. HACCP system is composed of five preliminary steps and the seven principles of the CODEX (Codex Alimentarius Commission, 2001). In comparison with other animal farms, dairy farms need more rigorous

\footnotetext{
*Corresponding author:

Insik Nam, Research Center for Environment Friendly and Quality Livestock Production Technology, Hankyoung National University, Anseong, 17579, Tel: +82-31-670-4630,, Korea. E-mail: isnam@hknu.ac.kr

Received: 03 January 2017; Revised: 21 September 2017; Accepted: 25 September 2017; Published Online: 05 October 2017
} 
sanitation and safety management systems to ensure the production of high-quality raw milk. In Korea, milk quality is based on protein, fat, and somatic and bacterial levels.

Therefore, by implementing the HACCP system, prevention of antibiotic overuse in animals or enhancement of milk quality is possible. Dairy farms in Korea began implementing the HACCP system in 2007. A total of 6,000 dairy farms are producing raw milk in Korea, of which 440 dairy farms are currently implementing the HACCP system based on the Livestock Products Sanitary Control Act (Korea Livestock Products HACCP Accreditation Service, KLPAS, 2016). However, there is a lack of information regarding the implementation and effects of the HACCP system on dairy farms.

Therefore, the goal of this study was to determine the effects of the implementation of the HACCP system on reproductive effectiveness of cattle, raw milk quality, and antibiotic requirements in Korean dairy farms.

\section{MATERIALS AND METHODS}

\section{Dairy farm and data survey}

In this study, the impacts of HACCP system implementation on regenerative productivity, milk quality, and antibiotic use in dairy farms were studied. To conduct this study, we used the HACCP education center at the Hankyoung National University to recruit dairy farms that had implemented the HACCP system. Typically, animal farms prepare the HACCP system with the aid of consultants for three to six months and then apply to the KOLPHAS, KOLPHAS then visits the farms and assesses them based on dairy farm HACCP evaluation standards. From each farm, the following data and raw milk sample were collected in this study: milk production quantity ( $\mathrm{kg} / \mathrm{head} /$ day), breeding interval (day/head), weaning period (day/head), somatic cell count in raw milk (cells $/ \mathrm{mL}$ ), number of bacteria in raw milk (cells $/ \mathrm{mL}$ ), milk fat and milk protein content, and monthly expenses for antibiotics. The number of the types of antibiotics used among categories was compared before and after HACCP system implementation for twelve months, and we gathered dairy records provided by the farms. All data were collected at 50 HACCP-system implemented dairy farms during April 1, 2015 to March 31, 2016. Basic information, such as average cattle composition of the 50 HACCP system implemented dairy farms is shown in Table 1. All dairy farms were managed by the Korea Animal Improvement Association (KAIA).

\section{Raw milk collection and analysis}

Raw milk was collected monthly and analyzed for the following: somatic cell count, number of bacteria, and fat and protein content. Thus, farmers can observe the quality and sanitation level of their raw milk. The analysis of milk was as follows, $30 \mathrm{~mL}$ of milk was collected in a plastic container and approximately $20 \mathrm{mg}$ of antioxidant (Broadspectrum Microtabs. II D\&F control system, Inc.) was added. Samples were stored at $4^{\circ} \mathrm{C}$ in a cold storage box and delivered to the lab within a day. Each milk sample was analyzed by an automatic milk analyzer (Automatic IR 4000/5000 Milk Analyzer, Foss Electric) for somatic cell count, number of bacteria, and fat and protein content (Sánchez et al., 2005).

\section{Statistical analysis}

Statistical analysis was conducted using the Statistical Analysis System program (SAS, 2002). Effects on reproductive effectiveness of cattle, milk quality, milk sanitation, and antibiotic requirements were tested using an analysis of variance (ANOVA). The differences between means of before and after HACCP system implementation were determined using a $t$-test. The level of statistical significance was $p<0.05$.

\section{RESULTS}

Table 1 provides general information on the average number of cattle at the 50 dairy farms in Korea. Overall, the dairy farms had an average of 103 cows. This was comprised of 11 calves (10.39\%), 37 growing cattle $(36.52 \%)$, and 58 lactating cows, including dry cows $(53.09 \%)$.

Table 2 shows an overview of average milk production, calving intervals, and weaning periods and provides information for before and after HACCP system

Table 1: Average cattle composition of 50 HACCP-implementation dairy farms in Korea

\begin{tabular}{lcc}
\hline Classification & $\begin{array}{c}\text { Number of } \\
\text { cows (head/farm) }\end{array}$ & Rate (\%) \\
\hline Calves & 11.08 & 10.39 \\
Growing cattle & 37.21 & 36.52 \\
Lactating cows (including dry & 58.33 & 53.09 \\
cows) & 103.21 & 100.00 \\
Overall &
\end{tabular}

Values are expressed as mean or percentage ( $\mathrm{n}=50$ dairy farms)

Table 2: Changes in productivity before and after HACCP implementation on dairy farms in Korea

\begin{tabular}{lccc}
\hline Item & \multicolumn{2}{c}{ HACCP system } & \multirow{2}{*}{ p value } \\
\cline { 2 - 3 } & \multicolumn{1}{c}{ Before } & After & \\
\hline $\begin{array}{l}\text { Milk production } \\
\text { (kg/head/day) }\end{array}$ & $28.7 \pm 0.63$ & $29.7 \pm 0.52$ & 0.22 \\
$\begin{array}{l}\text { Breeding intervals } \\
\text { (day/head) }\end{array}$ & $434.44 \pm 7.17$ & $419.89 \pm 5.17$ & 0.11 \\
$\begin{array}{l}\text { Weaning periods } \\
\text { (day/head) }\end{array}$ & $58.61 \pm 2.55$ & $59.72 \pm 2.81$ & 0.77 \\
\hline
\end{tabular}

Values are expressed as mean \pm standard error of the mean ( $n=50$ dairy farms) 
implementation changes at the dairy farms. In Korea, calves are provided with colostrum for 2-3 days using an artificial feeder and then go to the liquid feeding stage. The average milk production after the implementation of the HACCP was $29.7 \mathrm{~kg} / \mathrm{head} /$ day, showing only a $3.8 \%$ increase from $28.7 \mathrm{~kg} / \mathrm{head} /$ day before the implementation and these values were not statistically different. Implementation of HACCP had no significant effect on weaning period (59.7 vs. 58.7 days, Table 2). No significant difference was found for calving intervals after the implementation of HACCP (419.8 vs. 434.4 days).

Changes in milk quality before and after HACCP system implementation in dairy farms are shown in Table 3. Implementing the HACCP system on dairy farms significantly decreased the number of somatic cells in milk by $24.6 \%(p<0.05)$. On average, $18.4 \times$ $10^{3}$ (cells $/ \mathrm{mL}$ ) somatic cells were observed before the implementation of the HACCP system and an average of $13.7 \times 10^{3}$ (cells $\left./ \mathrm{mL}\right)$ cells was observed after the implementation of the HACCP system. Implementation of the HACCP system also tended to increase the rate of first grade milk production $(89.3 \%)$ compared to that of the nonHACCP implementation period (84.2\%). Bacterial number in milk after HACCP implementation was significantly lower $\left(0.51 \times 10^{2}\right.$ cells $\left./ \mathrm{mL}\right)$ compared to that which occurred before HACCP implementation $\left(0.73 \times 10^{2}\right.$ cells $\left./ \mathrm{mL}\right)$ $(p<0.05)$. Based on overall percentages, numbers of bacteria in milk decreased by $22.33 \%$ after the implementation of HACCP. HACCP implementation also affected the rate of first grade milk production $(98.00 \%$ after HACCP vs. 92.68\% before HACCP).

Fat and protein content in raw milk were not significantly affected by the implementation of the HACCP system (Table 4).

Table 5 shows the changes in antibiotic usage following HACCP system implementation. Monthly expenses for antibiotics at dairy farms decreased significantly $(p<0.05)$ after HACCP system implementation (549 USD/month) as compared to that prior to implementation of the HACCP system (871 USD/month). The number of different classes of antibiotic use after HACCP decreased, being
3.79 following implementation compared to 4.79 prior to implementation. These results suggested that non-HACCP implemented dairy farms have greater expenses for antibiotics than the farms that follow the HACCP system.

\section{DISCUSSION}

Throughout the world, livestock production safety is one of the most important public health concerns. This is because of threats, specifically milk-borne zoonotic diseases, such as bovine spongiform disease and food poisoning caused by bacterial organisms, such as Escherichia coli O157:H7, Salmonella spp, and Campylobacter spp. Antibiotic residues are also a concern in livestock products. The HACCP system is important in the dairy industry as it ensures the production of high-quality milk (Lievaart et al., 2005). Methods from the HACCP system provide a management framework wherein areas that needs improvement are stressed and identified. It is used to ensure the welfare of animals and the safety of the food produced (Noordhuizen and Welpelo, 1996).

Based on the results from this study, implementation of the HACCP system on dairy farms may not influence reproductive efficiency. Average milk yield ( $\mathrm{kg} / \mathrm{head} /$ day), calving interval (days), and weaning period (days) of average dairy farms in Korea were 27-30 kg/head/day (Ahn et al., 2005), 417-455 days (Baek et al., 2007), and 50-60 days (Khan et al., 2006), respectively. Our study did not detect any statistically significant differences before or after the implementation of HACCP.

In Korea, bacterial and somatic cell number in milk are used as important factors in the grading of milk. Therefore, dairy farmers strive to minimize bacterial and somatic cell number to obtain higher raw milk prices from milk processing companies. Various factors that influence bacterial and somatic cell number are sanitation management of feed, farm facility management, sanitation during milking, and mastitis management in dairy cows. Song and Chang (2007) reported that the implementation of the HACCP system in dairy farms could result in production of higher grade milk with lower numbers of

Table 3: Changes in milk quality before and after implementation of the HACCP system on dairy farms in Korea

\begin{tabular}{|c|c|c|c|c|}
\hline & \multirow[t]{2}{*}{ Item } & \multicolumn{2}{|c|}{ HACCP system } & \multirow[t]{2}{*}{$p$ value } \\
\hline & & Before & After & \\
\hline \multirow[t]{2}{*}{ Somatic cells } & No. somatic cell (cells/mL) & $18.39 \times 10^{3} \pm 1.00$ & $13.73 \times 10^{3 *} \pm 1.36$ & 0.01 \\
\hline & Rate of $1^{\text {st }}$ grade (\%) & $84.17 \pm 3.25$ & $89.33 \pm 4.27$ & 0.34 \\
\hline \multirow[t]{2}{*}{ Bacteria } & No. bacteria cell (cells/mL) & $0.73 \times 10^{2} \pm 0.06$ & $0.51 \times 10^{2 * *} \pm 0.01$ & 0.001 \\
\hline & Rate of $1^{\text {st }} \mathrm{A}$ grade $(\%)$ & $92.68 \pm 3.58$ & $98.00 \pm 0.90$ & 0.16 \\
\hline
\end{tabular}

Values are expressed as mean \pm standard error of the mean $\left(\mathrm{n}=50\right.$ dairy farms). somatic cells are expressed as number and rate of $1 \mathrm{st}$ grade $\left(1^{\text {st: }}>20 \times 10^{4} / \mathrm{mL}\right)$, bacteria are expressed as number and grade $\left(1^{\text {st }} \mathrm{A}:>3 \times 10^{4} / \mathrm{mL}\right)$, significant differences in values before and after HACCP implementation are indicated with asterisks $\left({ }^{*} p<0.05,{ }^{* *} p<0.001\right)$ 
Table 4: Changes in milk fat and protein content before and after HACCP system implementation on dairy farms in Korea

\begin{tabular}{lccc}
\hline \multirow{2}{*}{ Item } & \multicolumn{2}{c}{ HACCP system (\%) } & p value \\
\cline { 2 - 3 } & Before & After & \\
\hline Milk fat & $3.94 \pm 0.03$ & $4.03 \pm 0.04$ & 0.12 \\
Milk protein & $3.18 \pm 0.08$ & $3.18 \pm 0.09$ & 0.98 \\
\hline
\end{tabular}

Values are expressed as mean \pm standard error of the mean $(n=50$ dairy farms)

Table 5: Changes in animal medicine use before and after HACCP system implementation on dairy farms in Korea

\begin{tabular}{lccc}
\hline \multirow{2}{*}{ Item } & \multicolumn{2}{c}{ HACCP system (\%) } & p value \\
\cline { 2 - 3 } & Before & After & \\
\hline $\begin{array}{l}\text { Monthly expenses } \\
\text { for medicine (USD) }\end{array}$ & $871.94 \pm 101.09$ & $549.65^{\star} \pm 59.18$ & 0.01 \\
$\begin{array}{l}\text { The number of } \\
\text { different types of }\end{array}$ & $4.79 \pm 0.71$ & $3.79 \pm 0.80$ & 0.36 \\
$\begin{array}{l}\text { antibiotic used } \\
\text { (month) }\end{array}$ & & & \\
\hline
\end{tabular}

Values are expressed as mean \pm standard error of the mean $(n=50$ dairy farms), significant differences in values before and after HACCP implementation are indicated with an asterisk $\left({ }^{*} p<0.05\right)$

bacteria and somatic cells.

A portion of the general cattle health program is the administration of vaccines and medications guided by a schedule (Lievaart et al., 2005). Usually, a veterinarian gives medications or preventive treatments to cows. However, there are challenges that occur with the use of medication in dairy cattle, and the primary challenge is management. This includes, giving appropriate dosages of drugs, identification of treated animals, and most importantly, personnel compliance with the milking schedule, including the withdrawal period. Antibiotics have been used in the livestock industry for over 50 years, mainly to increase productivity and prevent various diseases. The practice of placing antibiotics in feed has become an integral part of nutritional strategies in livestock (Chinabut and Puttinaowarat, 2005). However, there is a growing concern over the extensive use of medication in the livestock industry. One concern is the opportunity for the development of antibiotic resistant pathogens and also the antibiotic residues left in animal products intended for human consumption (Chee-Sanford et al., 2001; Dowson et al., 1994; Hunter et al., 1992). The study revealed a significant reduction in monthly antibiotic expenses after implementing the HACCP system on dairy farms. A similar study showed the reduction of animal medical expenses after implementing the HACCP system in swine farms (Nam, 2010).

The HACCP system on dairy farms is composed of a prerequisite program and a HACCP management program. The prerequisite program consists of management of biosecurity, farm facilities, farm sanitation, feed medicine drinking water, disease, milking, and importation and shipment. Cho et al. (2010) suggested that implementation of the HACCP system on swine farms may provide beneficial effects, such as reduction of medical expenses, improved productivity, and increased safety of livestock products for consumers. Lee et al. (2008) also reported that implementation of the HACCP system in animal farms would improve the level of management of biological hazards in comparison to non-HACCP practicing animal farms. The decrease in somatic cell numbers in milk and expenses in veterinary medicine in HACCP practicing farms are believed to be a result of conducting the prerequisite programs.

\section{CONCLUSION}

The present study investigated the influence of HACCP implementation on raw milk quality, raw milk sanitation and veterinary medicine use in dairy farms. The number of somatic cell and bacteria decreased in raw milk by implementing HACCP. A prerequisite program on dairy farm HACCP includes 7 items of farm biosecurity management, 9 items of farm facilities management, 10 items of farm sanitation management, 11 items of feed $\cdot$ medicine $\cdot$ drinking water management, 6 items of disease management, 9 items of milking management and 6 items importation and shipment management. The quality and sanitation level of raw milk is considered to be improved by a prerequisite program of the HACCP. Implementation of HACCP in dairy farm is expected to provide safer dairy products to consumer.

\section{ACKNOWLEDGMENT}

The author would like to express sincere thanks to the 50 dairy farm owners for providing help and data to support this paper.

\section{REFERENCES}

Ahn, B. S., E. G. Kwon, G. H. Suh, H. J. Lee and B. K. Park. 2005 Comparison of milk composition and blood metabolites between high and low milk producing cows. Anim. Feed Sci. Technol. 47: 11-18.

Baek, K. S., W. S. Lee, S. B. Park, B. S. Ahn, S. J. Park, H. S. Kim, S. J. Kang, B. S. Jeon and J. K. Son. 2007. Survey on reproductive traits of average and high yielding Holstein cattle. J. Embryo Trans. 22: 111-114.

Chee-Sanford, J. C., R. I. Aminov, I. Krapac, N. Garrigues-Jeanjean and R. I. Mackie. 2001. Occurrence and diversity of tetracycline resistance genes in lagoons and groundwater underlying two swine production facilities. Appl. Environ. Microbiol. 67: 1494-1502.

Chinabut, S. and S. Puttinaowarat. 2005. The choice of disease control strategies to strategies to secure international market access for aquaculture product-progress. In: Fish Vaccinology 
$3^{\text {rd }}$ International Symposium on Fish Vaccinology, Bergen, Norway, p. 255-261.

Cho, J. J., D. G. Lim, S. H. Back, S. L. Pyo, W. C. Lee and I. S. Nam. 2010. Effects of HACCP system implementation on medicine use and productivity of swine farms in Korea. Korean J. Food Sci. Anim. 30: 392-396.

Codex Alimentarius Commission. 2001. Food Hygiene Basic Text, Codex Aliment Arius-Joint FAO/WHO Food Standards Programs. $3^{\text {rd }}$ ed. Bernan Association, Lanham.

Cullor, J. 1995. Implementing the HACCP program on your clients' dairies. Vet. Med. 90: 290-295.

Dowson, C. G., T. J. Coffey and B. G. Spratt. 1994. Origin and molecular epidemiology of penicillin-binding-protein-mediated resistance to beta-lactam antibiotics. Trends Microbiol. 2: 361366.

Hays, V. W. 1991. Effects of antibiotics. In: Pearson, A. M. and T. R. Dutson (Eds.), Growth Regulation in Farm Animals, Elsevier Applied Science, London, pp. 299-320.

Hunter, H. J., J. C. Shelley, J. R. Walter, C. A. Hart and M. Benneth. 1992. Apramycin resistance plasmids in Escherichia coli: Possible transfer to Salmonella typhimurium in claves. Epidemiol. Infect. 108: 271-278.

Khan, M. A., H. J. Lee, W. S. Lee, K. S. Ki, H. S. Kim, B. S. Ahn, S. B. Park, Z. S. Hong and Y. J. Choi. 2006. Effect of Ad libitum and restricted milk feeding on growth performance of Holstein calves. Korean J. Anim. Sci. Technol. 48: 871-880.

Kim, Y. Y., D. Y. Kil, H. K. Oh and I. K. Han. 2005. Acidifier as alternative material to antibiotics in animal feed. Asian Aust. J. Anim. Sci. 18: 1048-1060.

KLPAS. 2016. Statistics of HACCP implemented animal farms. Korea livestock products HACCP accreditation service. Anyang. 32: 430-731.

Lean, I. J. 2000. A hazards analysis critical control point approach to improving reproductive performance in lactating dairy cows. Asian Aust. J. Anim. Sci. 13A: 2-36.

Lee, J. M., I. S. Nam and J. H. Ahn. 2008. Effects of supplementation of ruminally protected amino acids on in vitro ruminal parameters and milk yield and milk composition of dairy cows in midlactation. Korean J. Anim. Sci. Technol. 50: 199-208.

Lievaart, J. J., J. P. Noordhuizen, E. van Beek, C. van der Beek, A. van Risp, J. Schenkel and J. van Veersen. 2005. The hazard analysis critical control points (HACCP) concept as applied to some chemical, physical and microbiological contaminants of milk on dairy farms. A prototype. Vet. Q. 27: 21-29.

Nam, I. S. 2010. Effects of HACCP system implementation on medicine use and productivity of medium scale swine farms in Korea. Korean J. Anim. Sci. Technol. 52: 71-76.

Noordhuizen, J., J. C. da Silva, S. Boerssema and A. Vieira. 2008. Applying HACCP-Based Quality Risk Management on Dairy Farms. Wageningen Academic Publication, Netherlands.

Noordhuizen, J. and H. Welpelo. 1996. Sustaynable improvement of animal health care by systematic quality risk management according to the HACCP concept. Vet. Q. 18: 121-126.

Rhodes, G., G. Huys, J. Swings, P. Mcgann, M. Hiney, P. Smith and R. W. Pickup. 2000. Distribution of ox tetracycline resistance plasmids between aeromonads in hospital and aquaculture environments: Implication of Tn1721 in dissemination of the tetracycline assistance determinant Tet A. Appl. Environ. Microbiol. 66: 3883-3890.

Sánchez, A., D. Sierra, C. Luengo, J. C. Corrales, C. T. Morales, A. Contreras and C. Gpnzalo. 2005. Influence of storage and preservation on fossomatic cell count and composition of goat milk. J. Dairy Sci. 88: 3095-3100.

SAS. 2002. SAS/STAT Software for PC, Release 6.02, SAS Institute Inc., Cary, NC, USA.

Song, W. I. and M. K. Chang. 2007. A case study on the application of hazard analysis critical control point on cow's milk production stage for dairy farm management. J. Agric. Manage. Policy. 34: 928-940.

Suh, D. K. and J. C. Song. 2006. Analysis of Salmonella enterica serotype Enteritidis isolated from human and chickens by repetitive sequence-PCR fingerprinting by antibiotic resistance and plasmid profiles. J. Vet. Sci. 7: 37-41. 